\title{
THE PROTECTION OF WOMEN UNDER LAW AND RELIGION: AN ANALYSIS
}

\author{
Kamal Ahmad Khan \\ Faculty of Law, University of Lucknow, Lucknow, Uttar Pradesh, India
}

\begin{abstract}
All human beings are born free and equal in dignity. Women like men should also feel safe and secure on the face this earth. The claim of a country to civilization depends upon its treatment provided to the women in their different roles like mother, daughter, sister and wife. The most certain test by which we may judge whether a country is really free is also the amount of security provided to the women in the society. Since men and women are considered as two wheels of vehicles of a society, the progress and all round development of a country depends upon harmonizing the skills and abilities of all sections of society regardless of caste, creed, religion and sex. History knows that in spite of religious sanctions and legal provisions, women have been discriminated for ages and they have not been given equal opportunities in many social, economic and cultural spheres, rather they have been victim of violence, exploitation and discrimination. The modern age is the age of transformation in the status of women all over the world. Women struggled towards new freedom and identities. Hence the consciousness among women increased leading to organization and global conferences and movement to modernization. Inseparable from the right is their guarantee-legal and political. Legal guarantee lies in the international conventions, declarations and constitutions. Political guarantee lies in the structure of the state which includes political parties and its electoral system. Another aspect of protection is the religious protection which has been used and misused from time to time. In this background the purpose of this paper is to discuss the different international conventions and constitutional provisions pertaining to the protection of women. Religious provisions particularly the Islamic law in books and practice will also be analyzed.
\end{abstract}

Keywords: Conventions, legal provision, religious norms, mindset and will of the authority

\section{INTRODUCTION}

Gender inequality exists all over the world, with different effects in different religions. These differences are primarily due to cultural legacies, historical development, geographic location and the religious norms which predominate in society. ${ }^{i}$ The status of women in society is an outcome of the interpretation of religious texts and of cultural and institutional set-up of religious communities. The role of religion varies across time and space. In the history of religions, the voice of women is rarely heard due to the patriarchal dispositions of societies in which these religions emerged, which eventually shifted some of the changes in the status of women triggered by these new religions.
All the religions of the world agree on the respect for women and their crucial role in family life, especially with emphasis on women as mothers and wives. They do not; however advocate emancipation in the sense of total equality with men. ${ }^{\text {ii }}$ Male and female roles are therefore much differentiated and also unbalanced in the world religions. The influence of women on the formation of religious norms and traditions is small. ${ }^{\text {iii }}$

\section{STATUS OF WOMEN UNDER DIFFERENT RELIGIONS}

\section{Romans and women}

Roman family was based on the paternal power or patria protest as. The head of the family was its sole representative, and he alone had any locus standi in the Councils of State. A daughter after marriage

Corresponding Author: kahmad@ rediffmail.com

$2^{\text {nd }}$ World Conference on Women's Studies 5-6 May 2016, Colombo, Sri Lanka 
became subject to a different authority. Legally she ceased to be a member of her father's hearth, and therefore no legal relationship existed between them and their grandfather's family. ${ }^{\text {iv }}$ Thus the status of Roman women may be summarized as under:

a. No women could be without guardian.

b. No marriage could take place without consent of the father.

c. In early times a father could even kill his son or daughter for disobedience or misconduct.

d. She became her husband's property, being sold and conveyed in much the same manner as goods were sold and delivered.

e. The husband could kill his wife for misconduct and adultery.

f. The wife's property passed to the husband on marriage.

g. No civil or public office could be held by women.

i. She could not adopt, nor could she be a surety or a tutor.

Such was the status of women as given by historians in an Empire which is considered to have been the most magnificent and civilized, and from which modern Europe has adopted many laws and is proud of having done so.

\section{Status of women in Greece}

The position of women in Greece was about the same, if not worse. The custom of selling daughters in marriage was general. The superiority of man over women was vehemently asserted on all sides. The Greek recognized two distinct orders of womanhood. Firstly the duty of wife was fidelity to her husband and secondly, there was mistress who subsisted by her fugitive attachments. Their movement in public was restricted. Lecky says that after the age of Plutarch the position of virtuous women was very low one. In case of inheritance, her male relations were preferred to her. Euripides, the great dramatist, puts in to the mouth his media the remark that "Women are impotent for good, but clever contrivers of all evil.",vi In Sparta such women as could not be expected to give birth to healthy children were often destroyed by order of the State, with the result the proportion of women to men decreased to such an extent that one wife had several husbands. It was also ordered, says Lecky, that the old or infirm husbands should cede their young wives to a stranger man who could produce vigorous soldiers for the state. ${ }^{\text {vii }}$

\section{JUDAISM AND WOMEN}

The women occupied a very inferior status in Hebrew society. "The Hebrew represented women as the source of evil and death on earth", "of the women came the beginning of sin, and through her we all die.",viii Lecky says: “-----------------the custom of purchase -money to the father of the bride was admitted. Polygamy was authorized and practiced by the wisest men on an enormous scale. A women was regarded as the origin of human ills,"ix

"By the Jewish law," says Howard, "as it still existed at the dawn of the present era, divorce was the one sided privileges of man". Polygamy among Jews continued right up to the twelfth century. The prohibition on polygamy by the end of $12^{\text {th }}$ century was attached with Jews living in Germany and Northern France; later on it was successfully adopted in all European countries. Nevertheless the Jewish Marriage Code retained many provisions which originated at the time when polygamy was still legally in existence. ${ }^{\mathrm{x}}$

The Jewish law of inheritance gives a restricted right of inheritance to women. She was not accepted as heir to her father in the presence of brother ${ }^{x i}$ Daughters were entitled to inheritance if she had no brother $^{\text {xii }}$

\section{CHRISTIANITY AND WOMEN}

Women under Christianity also find the deep injustice. The present status of women in Christian countries in the West has not been achieved by Christian reformer, but by social and political thinkers. 
The story of the fall of man as given in the Bible:

"And I will put enmity between thee (man) and the women----------it shall bruise the head, and thou shall bruise his heel,"xiii

"Unto the women He said, I will greatly multiply thy sorrow and thy conception; in sorrow thou shall bring forth children, and they desire shall be thy husband, and he shall rule over thee."xiv

The Bible again says, discussing the relative importance of sexes:

"For the man is not of the women, but the women of the man, , ${ }^{x v}$

"Neither was the man created for the women, but the women for the man,,

In the First Epistle of Paul and Apostle the Timothy we again find the following:

"Let the women learn in silence with all subjection,",xvii

"But suffer not women to teach, nor to usurp authority over the man, but to be in silence",xviii

"And Adam was not deceived, but the woman being deceived was in the transgression,"xix

Women is here made the scapegoat for her as well as Adam's sin. But for Eve, Adam would not have been banished from the Garden of Eden (Jannah) nor would there have been any necessity for the subsequent "Crucifixion of Jesus Christ.

Here there is difference between the notions understood in the Bible and the Holy Quran. In the Quran the fall of man was due not solely to the weakness of Eve, but to the weakness of both Adam and Eve. Both were transgressors, and both suffered.

Westermarck, commenting on the above expressions says, "you (woman) are the Devil's gate way; you are the first deserter of the divine law, you are she who persuaded him whom the Devil was not valiant enough to attack; you destroyed so easily God's image, Man. Your desert---------- that is, death--------------even son of God had to die.,

Lecky agreeing with Westermarck on the above line of thinking holds that women were forbidden by a Provincial Council (A.D. 578) in the sixth century on account of their impurity, to receive the Eucharist into their naked hands. Their subordinate position was continually maintained.

The religion which claim today to be Christianity is not the religion taught by the NAZARENE. Jesus had the profoundest respect and love for his mother, the Mary. Christ a model man never disregarded women. It is their disciples and those that came after him as servant and saints of church did degrade women and denied to her rightful place in society. Her emancipation in the West has been achieved by courageous social reformers.

\section{Legal status of women and the west}

The complete inferiority of the sex was continually maintained by the law. Girls were deprived of the right of inheritance of their father. Wherever the common law has been the basis of legislation the interest of wives and daughters were sacrificed till the close of the last century. ${ }^{\mathrm{xxi}}$

In England up till the 1883 as a general rule a married women contract was void though with certain exceptions a married woman could make a contract but she could not sue or be sued upon it apart from her husband.The married women's Property Acts of 1870 and 1874 enabled them to sue for such property and gave them all remedies. ${ }^{\text {xii }}$

The married women's Property Act 1880 provided additional rights to the women to acquire hold and dispose of property, real and personal possession, reversion or remainder, vested or contingent held by women.

\section{Women's liability for torts}

Under old common law a husband could be sued for torts committed by his wife. Now plaintiff has option to sue the wife separately if she has separate property or to sue jointly to the husband and the wife together. $^{\text {xxiii }}$ 


\section{Polygamy and Christianity}

Amir Ali writes that there is no intrinsic immorality or sinfulness in plurality of wives. St. Augustine, the Father of the Christian Church declared that polygamy in not a crime where it is a legal institution of a country, and the German reformers allowed and declared valid taking of a second or even a third wife, contemporaneously with the first, in default of issue or any other cause. ${ }^{\text {xiv }}$ The Emperor Valentine 11, by an Edict mentions that all the subjects of the Empire to marry several wives. Milton, the great English poet also narrates about practice of polygamy $^{\mathrm{xxv}}$

The Bible ${ }^{\mathrm{xxvi}}$ also admits polygamy:

"If he take him another wife, her food, her raiment, and her duty of marriage shall be not diminish"

\section{Divorce and Christianity}

The Protestants say "Yes" but the Roman Catholics asserts "No"

Milton called divorce "A law of moral equity, a pure moral economical law so clear in nature and reason that it was left to a man's own arbitration to be determined life of perpetual misery, and if young, to have recourse to immorality which is hurtful to the home, the church and the State. ${ }^{\text {xxvii }}$

\section{Pre-Islamic status of women}

As the sun of Islam rose above the azure horizon of this world, the world was divided in two groups: The first group consisted of the civilized nations, such as Roman Empire, the Persian Empire and other nations such as Egypt, Abyssinia, India and China. In these societies, women were the same as captives- they were completely deprived of autonomy and the general privilege of society.

The position of women under pre-Islamic Arabia may be summarized as under:

1. Unlimited polygamy prevailed

2. A man might marry as many as many wives as he could maintain.

3. Husband could repudiate the marriage at his will.

4. A widow was an integral part of heritage of husband.
5. Marriage between step-sons and mother in law were permissible and branded as Nikah-ul-Makht (shameful)

6. Polyandry was practiced by the halfJewish, half- Sabean tribes of Yamen,xxviii

The consent of women was not necessary in marriage. Widow by death of her husband was divided among heirs of husband like goods. Unrestricted polygamy sanctioned by usage was universally prevalent throughout Arab. Slave girl was in practice. The men of Magian religion could marry their own daughters and sisters. The word Talaq was in use. The practice of pronouncing Talaq many time and taking back in marriage was in use. Women were not free after Talaq until her husband let her free. Women among Arabs had no corresponding right to release herself from marriage bond. ${ }^{\mathrm{xxix}}$ The eagerness to have son and disregarded status of women an Arab father regarded the birth of a daughter as a calamity ${ }^{\mathrm{xxx}}$. They used to bury their daughters alive as soon as born. ${ }^{\text {xxi }}$ In case of succession, customary laws of heathen where females and minors were excluded daughters, wives, sisters and mother but maintenance she could claim. ${ }^{\text {xxii }}$

\section{ISLAM AND WOMEN}

"And We said: O Adam! Dwell you and your wife in the garden to depart from it a plenteous (food) wherever you wish, and do not approach this tree, for then you will be of the unjust,"xxxiii

"Then he(devil) caused them to fall by deceit, so when they tasted of the tree, their evil inclinations became manifest to them and they both began to cover themselves with the leaves of the garden, and their Lord called out to them: Did I not forbid you both from that tree and say to you that the devil is your open enemy?"xxxiv

The above description contradict the story that it was Eve, and Eve alone, who was responsible for the banishment of Adam and Eve from the Garden of Eden and only Eve committed sin.

Both crave forgiveness of the Almighty. "They said: Our Lord! We have been unjust to ourselves, and if 
Thou forgive us not, and have (not) mercy on us we shall certainly be of the losers." $\mathrm{xxxv}$

Therefore we find that in one stroke Islam banished the stigma from women that she is man's eternal seducer and tempter. Both men and women are liable to err and make mistake.

\section{Treatment with women}

The Quran condemns the practice of slaying girlinfants in the words: "And when the buried infant shall be asked for what sin she was slain." xxxvi

The holy Quran warns men against ill-treatment of women:

"O You who believe! It is not lawful for you that you should take women as heritage against (their) will; and treat them kindly; then if you hate them, it may be that you dislike a thing while Allah has placed abundant good in it."xxxvii

The Quran provides severe punishment for accusing unmarried women. The Quran says:

" And those who accuse free women, then do not bring four witnesses, flog them (giving) eighty stripes, and do not admit any evidence from them ever; and these it is that are the transgressors,"xxxviii

False accusation to wife and husband bears severe punishment like dissolution of marriage. If husband or the wife accuses the other of infidelity but cannot produce evidence in proof of lies or her allegation, in such cases a divorce is effected as neither party is punishable for the act. If the husband accuses his wife of infidelity the wife may claim divorce by a suit. ${ }^{\text {xxix }}$

Marriage under Islamic law should be with free consent of the woman. Amir Ali quoting Hidaya, says: "It is not lawful for a guardian to force an adult virgin into marriage. None, not even a father, nor the Sovereign, can lawfully contract a women in marriage, who is adult and of sound mind, without her permission whether she be a virgin or not."xl

\section{Islam and Polygamy}

Monogamy in Islam is a rule and polygamy an exception. The Quran says: "that it is more proper that a man have one wife, so that he may not deviate from the right course."xli The Quran further says: "that where the husband fears that he cannot do justice to more than one wife, he must not marry more than one woman at the same time."xlii The number of wives a man can have at the same time is limited to four.Thus Islam restricts the number as during pre-Islamic period a man could have as many wives as he liked. Law cannot be understood in isolation of the society. There is variety of situations which require polygamy to be adopted under exceptional circumstances, not only for the moral but also for the physical welfare of society. Prostitution, the great evil of civilization, is practically unknown to countries where polygamy is allowed as a remedial measure. Thus laws of Islam are practical, they have been framed with a view to meet both the normal and abnormal needs of human society. If you read theQuran, you will find in Sur-e-nisa that a man can marry two, three or four wives, but no more. The subsequent line declares 'But if you cannot deal equitably and justly with all, you shall marry only one.' This fact has been aptly narrated by Howard: "It is so among all Mohammedan people, in Asia and Europe, as well as in Africa, ninety-five percent of the Mohammedans of India, for instance are said to be monogamists, and in Persia, it is reported only two percent of the population enjoy the questionable luxury of a plurality of wives."xliii

\section{Islam and Polyandry}

Polyandry never existed in Islamic courtiers. The prohibition is contained in the verse 4:23 which enumerates the class of women forbidden in marriage. It is also unlawful for him to take in marriage one who is already married to another person. Only captive of war can be taken in marriage even though they are married to non Muslim subject to they become Muslim.

\section{Islam and Law of Divorce}

The principles of law of divorce in Islam may be summarized as under:

- Islam recognizes the necessity of divorce if the differences between husband and wife are irreconcilable, so that the general happiness of human relations may be maintained. $^{\text {xliv }}$ 
- Islam does not give unfettered power to the husband to divorce his wife. Various forms of restraint have been placed on the exercise of such power by him. ${ }^{\text {xlv }}$

- The true spirit of Islam is against the exercise of this power without sufficient cause. The condemnation of easy divorce causes a deterrent effect on society. ${ }^{\text {xlvi }}$

- Islam for the first time in human history provides wife a corresponding right to divorce herself from her husband. ${ }^{\text {xlvii }}$ Here Islam treats women more justly and equitably than other religions. The change in this respect was revolutionary one because so far Arabs regarded women as mere chattels and now the women were given a position equal in all respects to that of man which was previously never recognized by any nation or any reformer. ${ }^{\text {xlviii }}$

\section{Islam and Widow Re Marriage}

Islam is the only religion on the face of this earth which for the first time recognized remarriage of widow. In Arab the heirs of the deceased man used to inherit his widows but Islam gave them right to choose her won spouse without interference. The Quran says:

"And those of you who die and leave wives behind, they should keep themselves in waiting for four months and ten days, then there is no blame on you for what they do for themselves in a lawful manner, and Allah is aware of what you do,"xlix

"And there is no blame on you respecting that which you speak indirectly in the asking of (such) women in marriage or keep (the promise) concealed within your minds , 1

\section{Islam and Women's Right to Property}

Islam for the first time in human history talked about property right of women. ${ }^{\text {li }}$ It does not give unfettered power of testamentary disposition of one's property. The rights of heirs are guarded. All valid debts, funeral expenses, widow's dower, bequests etc. must be paid first before inheritance can be distributed. The rights of females are recognized although their shares are less than those of males. The reason for this provision may be:

Firstly, men are the chief bread winners and the wealth is generally increased by the efforts of men,

Secondly, women, before marriage are maintained by the father, and after marriage they are maintained and supported by their husbands. Thus their need for wealth generally is less than those of men. On the death of man, his mother, his widow and his daughters all inherit simultaneously. Their shares vary according as to whether the deceased had parents, wife and children or not. Broadly speaking the general policy of Islamic law is to recognize the rights of women to inherit as for as possible.

\section{Islam and Women's Right to Ownership}

The women as per direction of the Quran have right to possess, ownership and dispose of property, self acquired, received in dower debt, maintenance or by inheritance. No one either wife or husband can use or misuse property of the other. The Quran says:

"O you who believe do not devour your property among yourselves falsely, except that it be by trading by your mutual consent, and do not kill your people; surely Allah is merciful to you,"lii

"And whoever does this aggressively and unjustly, we will soon cast him into fire; and this is easy to Allah, ,liii

"And do not covet that by which Allah has made some of you excel others. Men shall have the benefit of what they earn and women shall have the benefit of what they earn; and ask Allah of His grace, surely Allah knows all things, ,liv

Abdur Rahim commenting upon the proprietary rights of women under Islam says that under Mohammedan law the husband does not acquire any right to or control over his wife's property by the fact of marriage. That is to say, a women's legal capacity is in no way affected by marriage. ${ }^{\text {lv }}$ Thus the position of wife and mother has been raised by Islam is clear from the provisions to right to maintenance, dower debt and custody of infant children ${ }^{\text {lvi }}$ 
Thus Islam views humanity as a superior unit, and men and women as equally human. Even though they are different in their femininity and masculinity, they are not different in their humanity.

\section{HINDUISM AND WOMEN}

\section{Social Status}

The social status of woman under Hinduism as per the religious text is unpleasant. Her status is very inferior to man. She is to remain under perpetual tutelage of her male relations as long as she lives. She is born to seduce man and lead them astray, and neither even a father is safe from his daughter, nor a son from his mother. ${ }^{\text {lviii }}$

\section{Polygamy and Hinduism}

Manu sanctioned polygamylix and child marriage.lxThe British courts in India also accepted that a Hindu may have without restriction any number of wives, and may marry again without consent, or any justification, except his own wish.lxiWidow Remarriage among the high caste Hindus, especially among Brahmins is nonexistent and prohibited. On the other hand, among the lower caste, widows are permitted to remarry.lxii The Brahminical prohibition reached to an extent that a widow was forcibly burned on the funeral pyre along with her husband's body, or if he died at a distance, was burned on a pyre of her own. This practice was prohibited by the Mogul Emperor, Akbar, the great and Lord William Bentinck (1829) who made Sattee culpable homicide.lxiii Thus we see that the attitude of Hindu law resembles very much the attitude of the Roman Catholic Church. Both regarded marriage as a sacrament, and holds the union of male and female to be indissoluble.

But it is irony of fact that there is a long gap between precept and practicelxiv. Materialistic approach of men towards philosophy of life have deviated them from the religious norms and teachings.

\section{MODERN LAW AND WOMEN}

Generally law cannot be divided according to gender. Whatever law applicable to men is also applicable to women equally. However, some enactments may be intended to exclusively women to uplift the dignity and status of women in society. In India there are nearly fifty Acts which are applicable to women.

Articles 12 to 35 of the Indian Constitution deal with fundamental rights of the people of India. Article 15 prohibits discrimination on ground of religion, race, cast, sex and place of birth. Article 16 prohibits discrimination in public services on the ground of religion, race caste and sex and place of birth. Articles 14, 19 (1), 21, 21 A, 20, 22, 23, 25 (1) 27, 28 (3) guarantee equal opportunities for women and men equally. Directive Principle of State Policy put man and woman on equal footing in respect of work and payment thereof, means of livelihood, education etc. In pursuance of Directive Principles of State Policy steps have been taken under Article 243, 243 A to 243D and Article $243 \mathrm{P}$ TO $243 \mathrm{Z}$ and part ix and part ix A added to the constitution of India by constitution $73^{\text {rd }}$ and $74^{\text {th }}$ amendment Act 1992 to guarantee political power to the women. Fundamental Duty under Article 51 A (e) provides: "It shall be duty of every citizen of India to promote harmony and the spirit of common brotherhood amongst all the people of India transcending, linguistic and regional or sectional diversities; to renounce practices to the dignity of women.

To make the provisions meaningful a monitoring body, the National Commission for Women has been established but the body lack teeth to bite the erring authority or person in case of exploitation of women. Most of the members including chairman are nominated by the Central Government and the State Governments. These members are generally associated with the government in power and they always deal the matters keeping in mind the governmental interest rather to protect the interest of women. Its report is not binding on the government.

\section{Family Courts}

In 1984 the Family Courts were establish to meet the matrimonial dispute separately. In practice a women has to pass the same ordeal as it happens in civil courts which make the justice denied.

\section{Special Provisions under Evidence Act 1872}

Evidence of character or previous sexual experience is not relevant in certain cases. ${ }^{\mathrm{lxv}}$ However, where the question of consent is in issue, evidence of the character of the victim or of such person, previous 
sexual experience with any person shall not be relevant on the issue of such consent or the quality of consent.

Presumption of abatement to commit suicide by wife is in favour of women. Law presumes that her husband and his relatives abated if wife commits suicide within seven years of the marriage. Similarly presumption in cases of dowry death, legitimacy of child and privileged communication are in favour of women. $^{\text {lxvi }}$

\section{Under Indian Penal Code, 1860}

Chapter 16, 20 and 22 of the Indian Penal Code deal with various kinds of offences against women and provides very harsh punishment to the guilty. The offences may be summarized as under:

- Offences affecting human body (S. 100),

- Causing death of women by any burns or bodily injury within seven years of marriage. (S. 304 B),

- Cruelty by husband or relatives of husband (S. 498 A),

- Causing miscarriage without women's consent, (S. 313),

- Voluntarily throwing or attempting to through acid on women, (S. 326 B),

- Outraging the modesty of women is punishable, (S. 354),

- Sexual harassment of women is punishable, (S.354 A, 354 B and 354C)

Sections 360, 363, 364 A, 366 B, 370 deal with trafficking of person. Section 375 and 376 applies to rape and section 376D deals with gang rape. Section 494,497 deal with bigamy and adultery respectively. Besides the above provisions following special laws have been framed to protect the women against the crime against their body and reputation:

- The Protection of Children from Sexual Offences Act. 2012,

- The Protection of Women from Domestic Violence Act. 2005,

- Controlling the Misuse of the Pre-natal Diagnostic Techniques 1994,
- The Indecent Representation of Women (Prohibition) Act 1986,

- The Commission of Sati (Prevention) Act 1987

- Immoral Traffic Prevention Act 1956

- Dowry Prohibition Act 1961

- Welfare and safety of women in the Factories Act. 1948,

- Equal Remuneration Act 1976 (in pursuance of Art. 39 of the Constitution of India)

Making law to sing with the tune of international community is as easy job, but making women to realize that they are safe and secure at the national level is a herculean task which require will of the society, character, mindset and culture of the persons implementing the provisions. Bombardment of unrestricted electronic media with vulgar scenes pertaining to women exposing their body leading to develop lust in teenagers and age-old men have made the women more prone to abuse and exploitation. ${ }^{\text {lxvii }}$ The case of exploitation of women reached 2074 in 2013 from 1316 in 2012 and the rape cases increased to $288 \%$ from 2003 to 2013 . Can the law protect the women at home? Who is responsible for such inhuman behavior? A state has to respond these questions first before making bulk of laws. Judiciary is helpless, it can only sort-out readymade solution to the problem that is why it held: "Sex in private is no misconduct ${ }^{\text {lxviii," }}$ and finally the Supreme Court legalized the concept of live- inrelationship. It is irony of fact that the women victim are still waiting to get benefit of 'NIRBHAYA FUND' and the Supreme Court had to ask the Central Government to formulate plan for relief and rehabilitation of rape survivors. ${ }^{\text {lxix }}$

\section{INTERNATINAL LAW AND THE PROTECTION OF WOMEN}

The need for protection of women has also been felt at the international level. Following steps have been taken for upliftment of women in the society: 
United Nations Charter, 1945 and the Women

Articles 1(3), 8 and 13(1) (b) lay down equality of men and women in the matters of promotion and observation of human rights and fundamental freedoms. In pursuance of the principle of the charter 1945 the ECOSOC established a commission on the status of women in 1946.

The Universal Declaration of Human Rights 1948 recognizes the equal rights of men and women. The convention on the Political Rights of Women 1953 provides: "women shall be entitled to vote in all elections on equal terms with men without any discrimination $^{1 \mathrm{xx}}$. Women shall be eligible for election in all publicly elected bodies, established by national laws, on equal terms with men without any discrimination. $^{\text {lxxi }}$ Women shall be entitled to hold public office and to exercise all functions, established by national laws, and equal terms with men, without discrimination. ${ }^{\text {lxxii }}$

Convention on the Nationality of Married Women 1957 protects nationality of married women: "Neither the celebration nor the dissolution of a marriage, not the change of nationality by the husband during marriage, shall automatically affect the nafftio0nality of wife." "xxiii Article 3 provides that each contracting state should guarantee the alien wife on her request the nationality of her husband through naturalization. The Convention on consent of marriage confers right on women to choose their husband with her free will. It also makes registration of marriage compulsory. It is worth mentioning here that this provision had been laid down as back as sixteen hundred years by the Islam.

The International Convention on Civil and Political Rights 1966 also talks about equality of men and women in respect to enjoyment of civil and political rights set forth in the convention. On the other hand International Covenant on Economic, Social and Cultural Rights 1966 uses the word non discrimination among men and women for enjoying economic, social and cultural rights.

The Declaration of the Protection of women and Children in Emergency and Armed conflict 1974 prohibits use of chemical weapons, degrading treatment and violence against women, repression including torture, imprisonment, destruction of dwelling etc. in the course of war and armed conflicts.

However, Convention on the Elimination of All Forms of Discrimination Against Women, 1979, Declaration on the Right to Development 1986, Declaration on the Elimination of violence Against Women, 1993 all of them emphasizes only on the aspects of equality and nondiscrimination. These declarations have simply persuasive effects on the states for implementing the objectives it lay down. It is important to mention here that the Committee established on the Elimination of Discrimination against Women is simply a recommendatory body. It may submit its report to the Secretary General of UNO, who shall transmit the reports of the Committee to the Commission on the Status of Women for its information. ${ }^{\text {lxxiv }}$ The committee may invite the specified agencies to submit reports on implementation of the Convention. ${ }^{\text {lxxv }}$ Here we see no coercive measure on the part of the international body to ensure the effective implementation of the objects and goals of the declarations mentioned above. CEDAW has been criticized for failing to declare when and where a national law government policy or countries practice constitute a breach of convention. CEDAW has never formally pronounced a State Party to be in violation of the convention even though many countries failed to carry on their obligations $^{\text {lxxvi }}$ on the $20^{\text {th }}$ anniversary of the Convention on the Elimination of All Forms of Discrimination against Women, Deputy SecretaryGeneral Louise Frechettee recognized how violence and discrimination against women pushes them to society's margin. The US government's commitment to women's rights around the world jeopardized by two competing foreign policy concerns:

i. The desire to promote advantageous economic and strategic relations with other governments regardless of human rights considerations ${ }^{1 x x v i i}$,

ii. The desire to protect US practices at home and abroad from scrutiny and criticism on human rights grounds. Besides this, preoccupied with keeping US citizens outside the courts' jurisdiction, the US played an obstructionist role. 


\section{CONCLUSION AND SUGGESSIONS}

Thus we see that most of the national and International instruments emphasize on two words: Equality and Non discrimination. These principles guarantee uniform treatment irrespective of the limitations which the women suffer. In other words women require special measures for their protection keeping in mind their physical attributes, modesty, dignity and security. Women need equality in fact, equality in law which prohibits discrimination of any kind is not sufficient. Women are weak, modest, vulnerable and shy. They need diversified approach for their protection so that they preserving their identity as women may develop their personality. Islam,like men presents women as complete members of the human society and equally considers each to be joint elements of the community but being a complete member of the society does not necessitate that all members of the society have identical rights and privileges. It is true that all members of the society must be equal before the law yet this equality is equality regarding the execution of the law i.e benefiting from justice- not equality in social value and determined rights. The ways in which discrimination against women manifested itself varied from one culture to another. There are many International Declarations, Conventions, Covenants and Protocol to protect the women against discrimination. A few of them talks about different needs to empower them. The governmental failure to change their national legislations made the International Covenant on Civil and Political Rights meaningless.

Now the question is who is going to implement the provisions of declarations, conventions and protocol?

Is there any coercive machinery at the international level to see whether the provisions laid down by the Declarations and Conventions are being followed in letter and spirit?

Are the States bound to follow the norms laid down by the World Community uniformly?

Is there any effective agency or machinery at the national level to scrutinize the effectiveness of special laws made under municipal law for protection of women?
Fear plays an important role in human life. The protection of women should be judged on the basis of intensity of fear among women community in respect of their security, property, liberty and modesty. History knows the armed conflicts and its effects on women. The alarming global dimensions of female targeted violence are not explicitly acknowledged by the international community. Rape is still being used as weapon of war, a strategy used to subjugate and terrify entire communities. Waging war by civilized nations for establishing selective democratic setup of government in selective regions on the plea of maintaining peace and justice in the world, left millions of women widow, homeless, sexually abused, compelled to migrate as refugee ${ }^{1 \times x v i i i}$ and become sex worker and prostitutes in neighboring countries $^{\text {lxxix }}$. The U N Peacekeepers forced girls to have sex with dog in Central African Republic but the response of the Secretary General Bon ki-moon was ' it is shocking to the core' and the French UN Ambassador called the incident "Sickening and odious" and promised exemplinary action. ${ }^{1 \mathrm{xx}}$ Who is responsible for such injustice and barbaric treatment with women community in this civilized world? Is this response of the highest authorities of the world community is effective and sincere to the cause of women protection?

However, making provisions, declarations, conventions and holding conferences to mourn on the pathetic conditions of women is not sufficient. A good provision may be a bad provision if the persons working behind them are of a bad lot. The true protection lies in the 'will' of the state and mindset of the persons involved in implementing the provisions.

So far as protection of women under religion is concerned it can be looked into keeping in mind the basic philosophy of the religion- the universe, mankind and society. Religion emphasizes not only on worldly life but also on life after death whereas man made laws are concerned with external behavior of man in its different form in the worldly life. Religion stresses on both internal and external purity, the modern law gives importance to external expressions. Religion is concerned with preventive measures, causes and cure of the disease which a man suffers on the other hand law is satisfied with cure by giving antibiotic. Sanction behind religion is both psychological and temporal and law talks about 
coercive force for implementation of law. Most of the religions lost its originality. The status of women as it is stated in different religion is the narration of persons of the time, who interpreted it according to the time and place either suited to the state or changing norms of the society. Islam, the latest edition of religion has diversified approach to the protection of women. It is concerned not only with rights but it is conscious enough to the duties towards society. Religion confers rights with corresponding duties keeping in mind the purpose of creation of the world and mankind who can achieve the object by leading a particular life style ${ }^{\text {lxxxi }}$. Religion emphasizes on character, human values and brotherhood. Law emphases on reason and see only biological phenomena of a man (women) ignoring its objective test. Men and women are two important wheel of chariot of life. She is as important as a man in life. Man and woman are equal up to certain extent but their role in society and need in life is different. Hence an identical equality may jeopardize the very object of creation and it is bound to fail. Compulsion cannot bring fruitful result unless the intrinsic traits of human beings are improved. Hence the teachings of morality, human values and charater oriented society are paramount to solve the problem. Law is not the brooding omnipresence up above the sky;it must have some connection with reality of thesociety. Hence there is a need to develop a kind of culture, respect, understanding and habit of sacrifice to the human values with open mind which may provide a real protection to the crying lot of women in the society.

\section{Let us pray: \\ O! The Women of the World!}

May God give you an unprecedented power,

May all humans elect you as their choice,

May they learn the lesson to follow the females.

i . Stump, R (2008), The Geography of Religion: Faith, Place and Space, Maryland, Roman and Littlefield Publishers.

ii . Kamila Khingorova, Department of Social Geography and Regional Development, Faculty of Science, Charles University in Prague, Check Republic, 2003.

iii. Helm, J, Women in Religion, 1994, p. 12, New York. iv . Hunter, Introduction to Roman Law, p. 37.

$\checkmark$. C.A.Soorma, The Status of Women in World Religions \& Civilizations, Dar -ul- Isha At- Kutub- E- Islamia, Bombay.

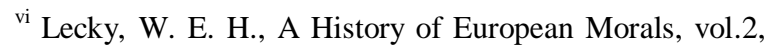
1869, p.306

vii Ibid. p. 308

viii Westermarck, E. Origin and Development of the Moral Ideas, vol.2,p.662, 1912-1917,

${ }^{\text {ix }}$ Lecky, W.E.H., A History of European Morals, vol.2, 1969, p. 308.

${ }^{\mathrm{x}}$ Mielziner, M., The Jewish Law of Marriage and Divorce, 1884., p.30

${ }^{x i}$ Kamaluddin, A. K., Status of Women In Islam, Dar-UlIsha At-Kutub-E-Islamia, Bombay, p. 78

xii Numbers 27:8, 9 "And thou shalt speak unto the children of Israel, saying, if a man die and have no son, then, ye shall cause his inheritance to pass unto his daughters".

xiii Gen. 3:15

${ }^{\text {xiv }}$ Gen. 3:16

${ }^{\mathrm{xv}} 1$ Cor. (11:8)

${ }^{\text {xvi }} 1$ Cor. (11:9)

xvii 1 Tim, (2:12)

xviii 1Tim, (2:12)

xix 1 Tim, (2:14)

${ }^{\mathrm{xx}}$ Westermarck, E., Origin and Development of the Moral Ideas, $2^{\text {nd }}$ edn., p. 6662

${ }^{\mathrm{xxi}}$ Lecky, p. 339.

xxii Anson, Law of Contract, p. 153.

xxiii Seroka v. Kattenberg, 1886, 17 QB.D. p.177,

Earl v. Kingscote, 1900, 2 ch, p.585, Court of Appeal.

Beaumont v. Kay, 1904, 1 KB., p. 292.

${ }^{\text {xxiv }}$ Amir Ali, Life and Teachings of Mohammad, p. 220

${ }^{\mathrm{xxv}}$ Milton, A Treaties on Christian Doctrine, p. 231

${ }^{x x v i}$ Exod. 21:10

xxvii Milton, Doctrine and Discipline of Divorce, Prose Works, 1ll, p.241-242

xxviii Amir Ali, Life and Teachings of Mohammad, p. 225.

${ }^{\text {xxix }}$ Abdur Rahim, Muhammedan Jurisprudence, p. 9-11

${ }^{x x x}$ Quran, Surat al-Nahl, 16:58-59 "And when one of them was given the good tidings of the birth of a girl, their face would darken in repressed anger. They would hide from the people because of the bad news they received asking themselves whether they should keep it in disgrace or bury it in the earth. Ah! Evil is that which they judge."

xxxi Abdur Rahim, Muhammedan Jurisprudence, p. 12, Amir Ali, Mohammedan Law, vol. 1l,p. 19

xxxii Ibid. p.16 
xxxiii Quran, 2:35

${ }^{\text {xxxiv }}$ Quran, 7:22

${ }^{x x x v}$ Quran, 7:23

xxxvi Surat al-Takwir 81:8,9

xxxvii Quran, 4:19

xxxviii Quran, 24:4

xxxix Mulla, Mohamedan Law, $8^{\text {th }}$ ed., p.194, Quran, 24:8, 24:7, 24:6, 24:4

${ }^{\mathrm{xl}}$ Amir Ali, Mohamedan Law, vol. 1l, p.279

xli Quran, 4:3

xlii Quran, 4:129,

xliii Howard, History of Matrimonial Institutions, vol. i., p. 142

xliv Quran, 4:35. (And if you fear a breach between the two, then appoint a judge from his people and a judge from her people; if they both desire agreement, Allah will effect harmony between them; surely Allah is knowing". If the differences are irreconcilable, then a divorce may be pronounced by the Qazi against the party at fault

${ }^{x l v}$ Quran, 4:35, 2:35,2:226, 2:227.

xlvi Abu Daud, 13:3, the holy Prophet said 'of all the things which have been permitted to men divorce is the most hated by Allah.

The right of divorce is to be exercised under exceptional circumstances. (Quran, 33:37)

xlvii Bukhari, 68:12, (Khula, Mubarat, Talak-e-tafweed) Amir Ali writes that a wife who has obtained a release from the marital tie by Khula or Mubarat is entitled to maintenance during her iddat period, (Amir Ali, Mohammedon Law, p. 580 )

xlviii Amir Ali, Mohammedon Law, vol. 1l, p.529-566.

xlix Quran, 2:234.

${ }^{1}$ Quran, 2:35

${ }^{l i}$ Quran, 4:11, 4:12, 4:117

lii Quran, 4:29

liii Quran, 4:30

${ }^{\text {liv }}$ Quran, 4:32

${ }^{\text {lv }}$ Abdur Rahim, Mohammadan Law, p. 333.

${ }^{\text {lvi } I b i d . ~ p . ~ 334, ~ M u l l a, ~ p . ~ 174, ~ A m i r ~ A l i, ~ p . ~ 293, ~ Q u r a n, ~ 2: 41 ~}$

lvii Quran, Surat Al- Imran 3:195, "I shall not leave unrewarded the work of any agent in you, whether man or woman; you are all members of the same race_ _, Surat Al-Hujurat 49:13- "O people! Surely, I have created you males and females and have made you +into (diverse) races and tribes that you may know one another. Verily, the most among noble among you before Allah is the most pious of you__"

lviii Manu, v. 148, "In childhood a female must be subjected to her father, in youth to her husband, when her lord is dead to her sons; a women must never be independent.", Manu, ix. 17, " (when creating them) Manu allotted to women (a love of their) bed, (of their) seat and (of) ornament, impure desires, wrath, dishonesty, malice, and bad conduct.",

Manu, ix. 14, "Though their passion for men, through their untenable temper, through their natural heartlessness, they become disloyal towards their husbands however carefully they may be guarded in this world.",

Manu, v. 154, "Though destitute of virtue, or seeking pleasure (elsewhere), or devoid of good qualities, (yet) a husband must be constantly worshiped as a god by a faithful wife."

Manu, ii.213. "It is nature of women to seduce men in this (world); for this reason the wise are never unguarded in (the company of) females."

Manu, ii. 215, "One should not sit in a lonely place with once mother, sister, or daughter; for the senses are powerful, and master even a learned man."

${ }^{\text {lix }}$ Manu, iii.12, "For the first marriage of twice - born men (wives) of equal caste are recommended; but for those who through desire proceed (to marry again) the following females, (chosen) according to the (direct) order (of the castes) are most approved."

Manu, viii. 204, Manu, ix. 85, 86, 87.

${ }^{\mathrm{lx}}$ Manu, ix. 94.

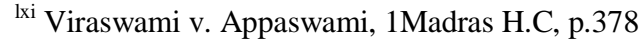

lxii Mulla, D. F., Principles of Hindu Law, $5^{\text {th }}$ ed. 1926, p.427.

lxiii Mayne, J.D., A Treaties on Hindu Law and Usage, $9^{\text {th }}$ ed. 1922, p. 115.

lxiv "If to do were as easy to as to know what were good to do, chapels has been churches, and the poor men's cottage, had been princes palaces". William Shakespeare, Quoted by Mohd Shabbir Khan, Status of Women in Islam, APH.Publishing Corporation, 2016. New Delhi

${ }^{\text {lxv }}$ Section 354, 354A, 354B, 354C, 354D, 376 A, to 376E. of the Indian Penal Code.

${ }^{\text {lxvi }}$ Sections 113 B, 122, 112 of the Indian Evidence Act.

lxvii Hindu, Oct. 13, 2012, "A 37 year old father raped his daughter of $6^{\text {th }}$ standard student at various times between July and Sept. 2012, in the presence of his wife and children."

lxviii Times of India, Allahabad High Court, Justice Katju and justiceRB Misra.

${ }^{\text {lxix }}$ Times of India, $28^{\text {th }}$ May, 2016, p.1.

${ }^{\text {lxx }}$ CPRW, Article 1

${ }^{\text {Ixxi }}$ Ibid. Article 2

lxxii Ibid, Article 3

lxxiii CNMW, Article 1

${ }^{\text {lxxiv }}$ CEDAW, Article 21

Ixxv Ibid, Article 22

${ }^{\text {lxxvi }}$ Khan, M.A., Women and Human Rights, SBS Pvt.Ltd., 2007, New Delhi. P.280 
Ixxvii Khan, M.A., Women and Human Rights, New Delhi, 2007, p.273, "the US government was less critical about blatant sex discrimination practices like Mexico, its second largest trading partner."

Ixxviii Hindu, Sept. 14, 2015, 'More than 350,000 refugees have tried to cross the Mediterranean Sea in to Europe.'

${ }^{\text {Ixxix }}$ Hindu, Sept. 14. 2015, p.11. "The root cause of refugee crisis in Central Asia is the pursuance of narrow political objectives sthat western powers entered West Asian territories and destabilized them. They cannot absolve themselves of all responsibility.

lxxx Times of India, April 2, 2016

lxxxi Quran, Surah Ahzab 33:35, The Quran praises righteous and worthy men and women similarly- "Verily, for Muslim men and women, for faithful men and women, for obedient men and women, for truthful men and women, for patient men and women, for humble men and women, for almsgiving men and women, for fasting men and women, for men and women who guard their private parts, and for men and women who remember God much, Allah has prepared forgiveness and a mighty reward." 